\title{
Antioxidant, Antimicrobial And Wound Healing Activity Of Salvadora Persica Twig Extracts
}

\author{
Pratima Tatke $^{1 *}$, Minakshi Nehete ${ }^{1}$ and Satish Gabhe ${ }^{2}$ \\ ${ }^{1}$ Professor, SNDT Women's University, India \\ ${ }^{2}$ Poona College of Pharmacy, India
}

Submission: February 10, 2017; Published: August 29, 2018

*Corresponding author: Prof. Pratima Tatke, CU Shah College of Pharmacy, SNDT Women's University, Santacruz (w), Mumbai, India, Tel: +91-9920685857; Email: patatke@gmail.com

\begin{abstract}
Wound healing is a complex multifactorial process that results in the contraction and closure of the wound and restoration of a functional barrier. Salvadora persica, commonly known as Miswak was found to contain constituents such as tannins, saponins, flavonoids and sterols. Hence it is thought to evaluate wound healing activity of Salvadora persica since phytoconstituents like tannins, saponins and flavonoids are known to promote the wound healing process due to their antioxidant and antimicrobial activities. Antimicrobial and antioxidant activities of Salvadora persica extracts were studied to understand mechanism of wound healing process. Total phenolic content (TPC) was estimated to screen the prepared extracts by using Folin-Ciocalteu phenol reagent method. Methanol extract showing highest TPC was undertaken for detailed antioxidant, antimicrobial and wound healing activities. Methanol extract showed moderate antioxidant activity on scavenging DPPH, ABTS radicals and by pyrogallol red bleaching method. Methanol extract also showed antimicrobial activity against wound pathogens by agar diffusion method. Methanol extract was formulated into gel and wound healing activity of gel was evaluated using incision and excision wound models in rats. Topical application of prepared gel on the excision wound in rats caused higher rate of contraction and reduced the period of epithelialization when compared to control group animals. In incision wound model, breaking strength of animals treated with the gel containing methanol extract of Miswak twig was found to be significantly $(\mathrm{p}<0.001)$ higher as compared to the control group animals. Hence, the present study revealed that gel containing methanol extract of Miswak twig possess wound healing activity.
\end{abstract}

Keywords: Incision wound; Excision wound; Antioxidant; Antimicrobial activity; Phytomedicines; Cholesterol plasma levels; DPPH; Ascorbic acid

Abbreviations: TPC: Total Phenolic Content; DPPH: 1,1-Diphenyl-2-picryl-hydrazy; AA: Ascorbic Acid; IAEC: Institutional Animal Ethic Committee

\section{Introduction}

Wound healing is an interaction of complex cascade of cellular and biochemical actions healing to the restoration of structural and functional integrity with regain of strength of injured tissues [1]. It involves continuous cell - cell interaction and cell matrix interactions that allow the process to proceed in different overlapping phases including inflammation, wound contraction, re epithelialization, tissue remodeling and formation of granulation tissue with angiogenesis [2]. These events are regulated by several mediators including platelets, inflammatory cells, cytokines and growth factors, and matrix metalloproteinases and their inhibitors [3].

Several factors such as bacterial infection, oxidative stress, necrotic tissue and interference with blood supply, lymphatic blockage and disease condition such as diabetes mellitus delay or reduce the wound healing process. Generally, if the above factors could be altered by any agent, an increased healing rate could be achieved [4].

Nature has gifted us with many herbs having mystical healing properties that are used widely in number of ailments.
The use of herbs and medicinal plants as the first medicine is a universal phenomenon. Today, as much as $80 \%$ of the world's population depends on traditional medicine as primary health care needs [5]. Many Plants and their extracts being antioxidant and/or antimicrobial actions have immense potential for the management and treatment of wounds. The phytomedicines for wound healing are not only cheap, well tolerated and affordable but are also purportedly effective and safe as hyper sensitive reactions are rarely encountered with the use of these agents [6]. These natural agents induce healing and regeneration of the lost tissue by multiple mechanisms. Herbal medicines in wound management also involve disinfections, debridement and provide a moist environment to encourage the establishment of the suitable environment for natural healing processes [7].

Salvadora persica (family Salvadoraceae) is an upright evergreen small tree or shrub. It is commonly known as Miswak or Tooth brush tree and is widely distributed in India, Africa, Saudi Arabia, Iran, Israel and Pakistan. It has been claimed in traditional literature to be valuable against a wide variety of diseases [8]. 
The traditional medicinal use of Salvadora persica as antimicrobial toothbrush stick for oral hygiene, and to treat gum inflammation, is a centuries old practice and a part of GreekoArab system of medicine [9]. Pharmacological studies indicated that Salvadora persica L. plant possess anti-microbial, anti-plaque, aphrodisiac, alexiteric, analgesic, anti-inflammatory, anti-pyretic, astringent, diuretic and bitter stomachic activities. It has great medicinal use in the treatment of nose troubles, piles, scabies, leucoderma, scurvy, gonorrhea, boils and toothache, to treat hook worm infections, venereal diseases, for teeth cleaning, in rheumatism, cough and asthma, to lower cholesterol plasma levels, reestablishment of the components of gastric mucosa, and as a laxative [10]. It contains important phytoconstituents such as vitamin C, salvadorine, salvadourea, alkaloids, trimethylamine, cyanogenic glycosides, tannins, saponins and salts mostly as chlorides [11].

However, there is no previous report on wound-healing activity of Salvadora persica twig in literature. The purpose of the present study was to investigate in vivo wound healing activity of Salvadora persica twig. Since antioxidant and antimicrobial agents play an important role in wound healing process, antioxidant and antimicrobial activities of Salvadora persica twig were carried out to find the mechanism behind wound healing process.

\section{Materials and Method}

\section{Materials}

Gallic acid, 1,1-Diphenyl-2-picryl-hydrazy (DPPH), ascorbic acid (AA), Folin-Ciocalteu phenol reagent, pyrogallol red, 2,2'azinobis (3- ethylbenthiazoline-6-sulphonic acid) (ABTS), potassium persulphate and all other substances used were obtained from Sigma- Aldrich Co. Ltd. Nutrient agar was obtained from Himedia (Mumbai, India). All chemicals used, including the solvents were of analytical grade.

\section{Plant materials}

The twig of Salvadora persica were collected from Malvani area in Malad, Mumbai, India and authenticated by Agharkar Institute, Pune, India.

\section{Methods}

\section{Extraction of plant material}

Authenticated plant material was further dried in shade, powdered and used for extraction. Extraction was carried out using various solvents such as Petroleum ether $\left(60-80^{\circ}\right)$, chloroform, methanol, 50\% aqueous alcohol and water. The extracts were concentrated in a rotary evaporator under pressure, were kept in desiccators and used for further studies.

\section{Determination of extractive value}

$10 \mathrm{gm}$ of powdered material were extracted with $100 \mathrm{ml}$ solvent using Soxhlet extraction apparatus. The \% yield of each extract was determined.

\section{In vitro antioxidant assay methods}

Phenolic compounds could be a major determinant of antioxidant potentials of foods and could therefore be a natural source of antioxidants [12]. Hence total phenolic content of the prepared extracts was determined to screen the bioactive extract.

\section{Determination of total phenolic content (TPC)}

The total phenolic content was measured using FolinCiocalteau reagent as per procedure described by Singleton et al., with some modifications [13]. Test mixture consists of $1 \mathrm{ml}$ of extract solution $(0.1$ or $1 \mathrm{mg} / \mathrm{ml}), 0.5 \mathrm{ml}$ of Folin Ciocalteau reagent and $5 \mathrm{ml}$ of distilled water. The mixture was incubated at room temperature for $10 \mathrm{~min}$. Then $1.5 \mathrm{ml}$ of anhydrous sodium carbonate solution $(10 \% \mathrm{w} / \mathrm{v})$ was added and the final volume was made upto $10 \mathrm{ml}$. The final mixture was allowed to stand at room temperature for $2 \mathrm{hr}$. The absorbance was measured at $725 \mathrm{~nm}$ using UV-Vis spectrophotometer. The experiment was carried out in triplicate. Gallic acid was used for preparing the standard curve $(10 \mu \mathrm{g} / \mathrm{ml}$ to $100 \mu \mathrm{g} / \mathrm{ml})$. The total phenolic content in the plant extract was expressed as milligrams of gallic acid equivalent per gram of dry weight (mg GAE/g) of extract.

The extract showing maximum TPC was further used for various in vitro antioxidant assays, antimicrobial activity and in vivo pharmacological activities.

\section{DPPH radical scavenging activity}

The free radical scavenging activity of active extract was measured by DPPH using the method of Blios [14]. An aliquot of $1 \mathrm{ml}$ of the extract solution in various concentration range was added to $3 \mathrm{ml}$ of $0.1 \mathrm{mM}$ DPPH solution. The decrease in the absorbance was determined at $517 \mathrm{~nm}$ after $30 \mathrm{~min}$. The percentage scavenging activity was calculated from [(A0-A1)/A0] $\times 100$, where $\mathrm{A} 0$ is the absorbance of the control, and A1 is the absorbance of the extract/ standard. A blank is the absorbance of the control reaction (containing all reagents except the test compound). The \% scavenging activity and IC50 value of each extract was calculated for the various concentrations. Ascorbic acid was used as standard antioxidant for comparison.

\section{Peroxynitrite pyrogallol red bleach method}

Pyrogallol Red solution $(100 \mu \mathrm{M})$ was prepared in $100 \mathrm{mM}$ phosphate buffer, pH 7.4. $1 \mathrm{ml}$ of extract solution was added to $2 \mathrm{ml}$ of $100 \mu \mathrm{M}$ Pyrogallol Red solution. $0.5 \mathrm{ml}$ of $200 \mu \mathrm{M} /$ liter peroxynitrite solution was added to the mixture and vortexed immediately. After 15 minutes the absorbance was measured using UV-Vis spectrophotometer at $540 \mathrm{~nm}$. The \% inhibition of pyrogallol red bleaching was determined using the formula [(A1-A2)/A1] X 100, where A1 is the absorbance in presence of antioxidants and $\mathrm{A} 2$ is the absorbance in absence of antioxidants. The IC50 values yielding 50\% inhibition of Pyrogallol Red bleaching were estimated. Ascorbic acid was used as standard antioxidant for comparison [15].

\section{ABTS assay}

ABTS was dissolved in water to a $7 \mathrm{mM}$ concentration. ABTS radical cation (ABTS+.) was produced by reacting ABTS stock solution with $2.45 \mathrm{mM}$ potassium persulfate and allowing the mixture to stand in the dark at room temperature for 12-16 hr. 
The ABTS+. solution was diluted with a phosphate buffer $(2 \mathrm{mM}$, $\mathrm{PH} 7.4)$ to achieve an absorbance of $0.8 \pm 0.014$ at $734 \mathrm{~nm}$. Extract solutions were mixed with ABTS+. solution, and after 1 min the absorbance was read using UV-vis spectrophotometer at $734 \mathrm{~nm}$. Phosphate buffer solution was used as a blank. The $\%$ radical-scavenging activity of the samples was determined using the formula $\left[\left(A_{\text {control }}-A_{\text {test }}\right) / A_{\text {control }}\right]$ X 100, where $A_{\text {control }}$ is the absorbance of the control (ABTS+• solution without test sample) and $A_{\text {test }}$ is the absorbance of the test sample (ABTS+• solution with extract). The $\mathrm{IC}_{50}$ values scavenging $50 \%$ of $\mathrm{ABTS}^{+\cdot}$ were estimated. Ascorbic acid and Trolox were used as standard antioxidants for comparison [16].

\section{Antimicrobial activity}

In vitro antibacterial and antifungal activities of methanol extract of bark of Miswak twig were determined by the agar diffusion method against wound pathogens [17]. Bacteria such as Pseudomonas aeruginosa (NCIM 2200), Staphylococcus aureus (NCIM 5022), Streptococcus pyogenes (NCIM 2608), Clostridium perfringens (NCIM 2677), Escherichia coli (NCIM 2065), Klebsiella pneumonia (NCIM 5082), Klebsiella aerogens (NCIM 2239) and fungal such as Candida albicans (NCIM 3471), Aspergillus niger (NCIM 1196) were used as test organisms. The cultures of organisms were procured from NCL (National Chemical laboratory) Pune, India and tested. The petri plates were prepared by pouring melted nutrient agar inoculated with 16 to $18 \mathrm{hr}$ old culture test organisms in a sterile petri dish. Cups were bored in agar by means of sterile cork borer and were filled with either extract to be tested or standard or control and incubated at 37 ${ }^{0} \mathrm{C}$ for $18-20$ hours. Mixture of dimethyl sulfoxide and water were used as control. Chloramphenicol was served as standard when efficacy was tested against bacteria while fluconazole was served as standard for fungi. Diameter of each zone of inhibition was measured and compared with standard.

\section{In-vivo pharmacological activities}

Methanol extract of Salvadora persica twig was formulated into $1.5 \%$ Carbopol 971 P NF gel by using extract (1\%), ethanol, propylene glycol, triethanolamine and distilled water. Prepared gel was evaluated for skin irritation and wound healing activities.

\section{Animals}

Albino Wistar rats of either sex weighing 180-200g were used for the study. The animals were procured from Haffkine Biopharmaceuticals, Mumbai, India. All animals were housed in polypropylene cages under standard experimental conditions with $26 \pm 2{ }^{\circ} \mathrm{C}$ ambient temperature and $12 \mathrm{~h}$ light-dark cycle. The animals were fed standard pellet diet and were provided water ad libitum. All experimental protocols were approved by the Institutional Animal Ethic Committee (CUSCP/IAEC/10 /2013) of C. U. Shah College of Pharmacy, Santacruz (w), India.

\section{Skin irritation studies}

Skin irritation study was conducted on albino rats as per OECD guide lines No. 404 (OECD, 2004) in order to evaluate safety of prepared topical gel [18]. The back of the albino rats was shaved to remove the fur carefully, 24 hours before application of the sample. Prepared topical Carbopol gel containing methanol extract of Salvadora persica twig was applied on the skin patches of albino rats and the site of application in terms of erythema and edema was examined at 24, 48 and 72 hours for changes in any dermal reactions. The irritation index was calculated to assess the irritation potential of the prepared Carbopol gel according to Draize Test [19].

\section{In vivo evaluation of wound healing}

Incision and excision wound models were used to evaluate the wound-healing activity of prepared topical Carbopol gel containing methanol extract of Salvadora persica twig.

\section{Grouping of animals}

For excision and incision wound study, male Wister rats (160$180 \mathrm{~g}$ ) were selected and were divided into four groups of six animals each. Rats were anesthetized with sodium pentobarbitone injection (45mg/kg, i.p.) and depilated at the predetermined site before wounding. Animals were divided into four groups of six animals each.

Treatment (Group I): Received with topical application of Carbopol gel containing methanol extract of Salvadora persica twig

Positive control (Group II): Received topical application of standard drug ointment i.e. Betadine

Negative (vehicle) control (Group III): Received with topical application of plain Carbopol gel

Negative control (group IV): Animals were left without any treatment

For both excision and incision wound models, the treatment groups were classified and treated in the same manner.

\section{Excision wound model}

An excision wound was inflicted by cutting away approximately $500 \mathrm{~mm}^{2}$ full thickness of the predetermined area on the anterior-dorsal side of each rat. Each rat was kept in a separate polypropylene cage and was provided with food and water ad libitum. All the test formulations were applied starting from day 0 till complete epithelialization. Wound-healing property was evaluated by \% wound contraction percentage and time of wound closure. The wound area was measured immediately by placing a transparent paper over the wound and tracing it out, area of this impression was calculated using the graph sheet. The same procedure is employed every fourth day and wound contraction was expressed as percentage of contraction. The period of epithelialization was calculated as the number of days required for falling off of the dead tissue remnants without any residual raw wound [20].

\section{Incision wound model}

A paravertebral long incision of $6 \mathrm{~cm}$ length were made through the skin and cutaneous muscle. 
After the incision was made, the two ends of the wound were closed with interrupted sutures with stitches $1 \mathrm{~cm}$ apart using sterile surgical thread and a curved needle. Carbopol gel containing methanol extract of Salvadora persica twig, plain Carbopol gel and Betadine were applied for 9 days. The sutures were then removed on the $8^{\text {th }}$ post - wounding day and the breaking strength of 10-day old wound was measured by tensiometer [21].

\section{Statistical analysis}

Results were expressed as means \pm SEM (Standard Error of The Mean). Comparisons between groups were performed using one way ANOVA followed by Turkey's pair-wise comparison test on Graph Pad Instat 3 statistical software.

\section{Results and Discussions}

\section{Extraction}

The extraction process yielded $1.062 \% \mathrm{w} / \mathrm{w}$ of petroleum ether extract, $2.24 \% \mathrm{w} / \mathrm{w}$ of chloroform extract, $17.07 \% \mathrm{w} / \mathrm{w}$ of the methanol extract, $16.09 \mathrm{w} / \mathrm{w} \%$ of the of water extract and $5.18 \% \mathrm{w} / \mathrm{w}$ of $50 \%$ aqueous alcoholic extract (Table $1 \& 2$ ).

Table 1: Determination of \% yield of extracts of Salvadora persica twig.

\begin{tabular}{|c|c|c|}
\hline Sr. No. & Solvents & Yield (\% w/w) \\
\hline 1 & $\begin{array}{c}\text { Petroleum ether }(60- \\
\left.80^{\circ} \mathrm{C}\right)\end{array}$ & 1.062 \\
\hline 2 & Chloroform & 2.24 \\
\hline 3 & Methanol & 17.07 \\
\hline 4 & Water & 16.09 \\
\hline 5 & $50 \%$ aqueous alcohol & 5.18 \\
\hline
\end{tabular}

Table 2: Determination of Total Phenolic Content (TPC) of extracts of Salvadora persica twig.

\begin{tabular}{|c|c|c|}
\hline Sr. No. & Solvents & $\begin{array}{c}\text { mg GAE/gm of } \\
\text { extract } \pm \text { SD }\end{array}$ \\
\hline 1 & $\begin{array}{c}\text { Petroleum ether }(60- \\
\left.80^{\circ} \mathrm{C}\right)\end{array}$ & $13.1 \pm 2.504$ \\
\hline 2 & Chloroform & $16.35 \pm 1.132$ \\
\hline 3 & Methanol & $125.6 \pm 0.7$ \\
\hline 4 & Water & $36.33 \pm 1.053$ \\
\hline 5 & $50 \%$ aqueous alcohol & $55.3 \pm 0.8752$ \\
\hline
\end{tabular}

\section{In vitro antioxidant assay methods}

Determination of Total Phenolic Content (TPC): The estimation of total phenolic content of the different extracts revealed a high phenol content in the methanol extract i.e. $125.6 \pm 0.7 \mathrm{mg} / \mathrm{g}$ gallic acid equivalent (GAE) followed by $50 \%$ aqueous alcohol extract ( $55.3 \pm 0.8752 \mathrm{mg} / \mathrm{g} \mathrm{GAE})$, water extract $(36.33 \pm 1.053 \mathrm{mg} / \mathrm{g} \mathrm{GAE})$, chloroform extract $(16.35 \pm 1.132 \mathrm{mg} / \mathrm{g}$ GAE ) and petroleum ether extract $(13.1 \pm 2.504 \mathrm{mg} / \mathrm{g}$ GAE) by reference to standard curve $(y=0.011 x+0.011$ and $r 2=0.998)$ (Table 1).

DPPH radical Scavenging activity: Anti-oxidant activity of Miswak twig was studied by inhibition the stable free radical DPPH. The amount of extract/standard needed for $50 \%$ inhibition (IC50). Methanol extract of Salvadora persica twig showed DPPH scavenging activity at higher $\mathrm{IC}_{50}$ value of $63.88 \mu \mathrm{g} / \mathrm{ml}$ as compared to standard ascorbic acid $(10.99 \mu \mathrm{g} / \mathrm{ml})$.

Assessment of pyrogallol red bleaching by peroxynitrite: The plant extract and standard exhibited inhibition of bleaching by Pyrogallol Red method indicating peroxy nitrite scavenging activity. Standard ascorbic acid was able to inhibit bleaching of Pyrogallol Red at $\mathrm{IC}_{50}$ value of $38.08 \mu \mathrm{g} / \mathrm{ml}$. However methanol extract of Salvadora persica twig showed less inhibitory activity with IC50 value of $783.48 \mu \mathrm{g} / \mathrm{ml}$ as compared to standard ascorbic acid.

ABTS scavenging assay: Standard ascorbic acid was able to scavenge ABTS radical at $\mathrm{IC}_{50}$ values of $7.23 \mu \mathrm{g} / \mathrm{ml}$. Methanol extract of Salvadora persica twig exhibited moderate free radical scavenging activity by ABTS method with $\mathrm{IC}_{50}$ values of $108.24 \mu \mathrm{g} /$ $\mathrm{ml}$.

In the present study antioxidant activity levels were found to be relatively high in the methanolic extract of Miswak twig by DPPH, ABTS and Pyrogallol bleaching method; hence oxidative stress may be reduced which is associated with impaired or delayed wound healing process (Table 3 ).

Table 3: Free radical scavenging activity of methanolic extract of Salvadora persica twig by DPPH, ABTS scavenging and pyrogallol red bleaching methods.

\begin{tabular}{|c|c|c|c|c|}
\hline \multirow{2}{*}{ Sr. No. } & \multirow{2}{*}{ Samples } & \multicolumn{2}{|c|}{ IC $_{50}$ Values of Samples $(\mu \mathrm{\mu g} / \mathrm{ml})$} \\
\cline { 3 - 5 } & $\begin{array}{c}\text { DPPH } \\
\text { Scavenging } \\
\text { Assay }\end{array}$ & $\begin{array}{c}\text { ABTS } \\
\text { Scavenging } \\
\text { Assay }\end{array}$ & $\begin{array}{c}\text { Pyrogallol } \\
\text { Red } \\
\text { Bleaching } \\
\text { Assay }\end{array}$ \\
\hline \multirow{2}{*}{1} & $\begin{array}{c}\text { Methanolic } \\
\text { extract of } \\
\text { Salvadora } \\
\text { persica } \text { twig }\end{array}$ & $85.67 \pm 1.85$ & $49.10 \pm 2.07$ & $\begin{array}{c}336.50 \pm \\
5.74\end{array}$ \\
\hline 2 & $\begin{array}{c}\text { Ascorbic } \\
\text { acid }\end{array}$ & $10.99 \pm 0.22$ & $7.23 \pm 0.61$ & $38.08 \pm 0.44$ \\
\hline
\end{tabular}

\section{Antimicrobial activity}

The methanol extract from Salvadora persica twig has shown inhibition effects on the growth of all the organisms tested. Amongst the test organisms used, Clostridium perfringens, Candida albicans, Pseudomonas aeroginosa, Staphylococcus aureus were found to be most sensitive to methanol extract of a Salvadora persica twig followed by Klebsiella pneumoniae, Aspergillus niger, Streptococcus pyogenes, Escherichia coli, Klebsiella aerogens. Microbial infection of wounds delays healing and causes a more pronounced acute inflammatory reaction which can lead to further tissue injury and damage. The antimicrobial activity of the extract on wound pathogens partly contribute to the wound healing effect by eliminating infection thus allowing the natural tissue repair processes to start. Hence the results of this study confirm that the herbs possess anti-bacterial activity and this will help keep the wound area sterile, thus promoting wound healing. This fact supports a faster wound healing in the treated groups compared with the control group (Table 4). 
Table 4: Antimicrobial activity of methanol extract of Salvadora persica twig against wound pathogens.

\begin{tabular}{|c|c|c|c|}
\hline \multirow{2}{*}{ Sr. No. } & Microorganisms & \multicolumn{2}{|c|}{ Zone of inhibition (mm) } \\
\cline { 3 - 4 } & $\begin{array}{c}\text { Methanol Extract of } \\
\text { Salvadora Persica Twig } \\
\text { (50mg/well) }\end{array}$ & Standard \\
\hline 1 & $\begin{array}{c}\text { Pseudomonas } \\
\text { aeruginosa }\end{array}$ & $5.67 \pm 0.58$ & $10 \pm 0.00$ \\
\hline 2 & $\begin{array}{c}\text { Staphylococcus } \\
\text { aureus }\end{array}$ & $5.00 \pm 0.00$ & $14.33 \pm 0.58$ \\
\hline 3 & $\begin{array}{c}\text { Streptococcus } \\
\text { pyogenes }\end{array}$ & $2.33 \pm 0.58$ & $12.67 \pm 0.58$ \\
\hline 4 & $\begin{array}{c}\text { Escherichia coli } \\
\text { Klebsiella } \\
\text { pneumonia }\end{array}$ & $3.33 \pm 0.58$ & $17 \pm 0.00$ \\
\hline 5 & $\begin{array}{c}\text { Klebsiella } \\
\text { aerogens }\end{array}$ & $1.33 \pm 0.58$ & $11 \pm 1.00$ \\
\hline 9 & $\begin{array}{c}\text { Clostridium } \\
\text { perfringens }\end{array}$ & $17 \pm 0.00$ & $18 \pm 0.00$ \\
\hline 7 & Candida albicans & $6.00 \pm 0.00$ & $13 \pm 0.00$ \\
\hline 8 & Aspergillus niger & Nil & Nil \\
\hline
\end{tabular}

\section{In vivo pharmacological activities}

Skin irritation study: Carbopol gels containing methanol extract of Salvadora persica twig showed no erythema or oedema on intact rat skin. The primary skin irritation index of the gels was calculated as 0.00 . The results indicated that all Carbopol gels did not cause any skin reaction after examining at 24, 48 and $72 \mathrm{hrs}$. Since the primary skin irritation index of the creams was calculated as 0.00 , it can be classified as non-irritant and were found to be safe for topical application.

Excision Wound Study: Table 5 records the reduction of wound area of the different groups over the period of 24 days. It was seen that the faster healing of wound took place in case of animals, which received Carbopol gel containing Miswak extract of Salavadora persica twig and standard. The least rate of wound healing was seen in control group (no treatment) and vehicle control group which received plain Carbopol gel (without extract). A very rapid closure of the wound in the both Carbopol gel containing Miswak extract of Salavadora persica twig and standard treated groups observed between 4 and 8 days of post surgery. After day 8 of post surgery, wound closure was gradual till the total closure of the wound. Total wound closure was observed by the 22 day of post surgery in Carbopol gel containing methanol extract of Salavadora persica twig and by 25 day in control group. On $16^{\text {th }}$ day, wound contraction of standard group was found to be significant $(\mathrm{p}<0.001)$ in comparison to control group. The period of epithelization of standard group (16 days) was also found to be significantly $(\mathrm{p}<0.001)$ low as compared to control group $(25$ days).

Table 5: Effect of topical application of Carbopol gel containing methanol extract of Salvadora persica twig on wound contraction of excision wound.

\begin{tabular}{|c|c|c|c|c|c|}
\hline \multirow{3}{*}{ Sr. No. } & \multirow{3}{*}{ Post Wounding Days } & \multicolumn{4}{|c|}{$\%$ Wound Contraction } \\
\hline & & Group 1 & Group 2 & Group 3 & Group 4 \\
\hline & & Salvadora persica extract & Betadine & Plain gel & control \\
\hline 1 & 4 & $54.77 \pm 12.24$ & $56.04 \pm 20.10$ & $28.59 \pm 7.29$ & $30.47 \pm 16.65$ \\
\hline 2 & 8 & $81.55 \pm 8.40$ & $83.47 \pm 17.162$ & $62.36 \pm 8.36$ & $59.52 \pm 9.13$ \\
\hline 3 & 12 & $88.33 \pm 5.293$ & $95.92 \pm 3.80$ & $78.98 \pm 6.01$ & $76.21 \pm 4.805$ \\
\hline 4 & 16 & $91.85 \pm 6.63$ & $98.7 \pm 2.06^{* * *}$ & $88.52 \pm 3.00$ & $84.05 \pm 3.40$ \\
\hline 5 & 20 & $95.46 \pm 5.45$ & 100 & $93.06 \pm 1.38$ & $89.61 \pm 2.66$ \\
\hline 6 & 24 & 100 & & 100 & $96.61 \pm 2.85$ \\
\hline
\end{tabular}

Incision wound model: Table 6 compares the tensile strength of the healing skin treated with different gels measured on $10^{\text {th }}$ days. The results of the incision wound healing studies are presented as mean weight in gram \pm SD required to break open the resutured wound. The animals treated with methanolic extract and standard showed significant $(\mathrm{p}<0.001)$ increase in breaking strength $(607.33 \pm 8.07 \mathrm{gm}$ and $614.33 \pm 8.80$ respectively) as compared to the control group animals (406.50 $\pm 9.16 \mathrm{gm})$. This observation confirms that the methanol extract of Salavadora persica twig possesses excellent wound healing property so far as tensile strength of wound healing tissue is concerned.
Table 6: Effect of topical application of Carbopol gel containing methanol extract of Salvadora persica twig on breaking strength of incision wound.

\begin{tabular}{|c|c|c|}
\hline Sr. No. & Samples & Breaking strength (gm) \\
\hline 1 & $\begin{array}{c}\text { Methanolic extract of } \\
\text { Salvadora persica twig }\end{array}$ & $607.33 \pm 8.07^{* * *}$ \\
\hline 2 & Standard (Betadine) & $614.33 \pm 8.80^{* * *}$ \\
\hline 3 & $\begin{array}{c}\text { Vehicle control (Plain } \\
\text { carbopol gel) }\end{array}$ & $409.17 \pm 9.56$ \\
\hline 4 & Control & $406.50 \pm 9.16$ \\
\hline
\end{tabular}




\section{Conclusion}

Results obtained in the present study have shown the antioxidant and antimicrobial activity of methanol extract of Miswak twig. Thus, the external application of methanol extract of Salvadora persica twig on the wound prevented the microbes to invade through the wound, resulting protection of wound against the infections of the various microorganisms. At the same time, external application of the extract entrapped the free radicals liberated from the wound surrounding cells, which are having inherent machinery to protect the cells from the microbes. The faster rate of wound closer in excision wound model indicates the better efficacy of medication the increase in tensile strength of wounded skin indicates the promotion of collagen fibers. The increased tensile strength reveals that the disrupted surfaces are firmly knit by collagen. The synergistic effect of both antimicrobial and antioxidant activity, increased wound contraction and breaking strength accelerated the wound-healing process. Hence, present study confirms the promising wound healing activity of Salvadora persica twig.

\section{Referencers}

1. Kumarasamyraja D, Jeganathan NS, Manavalan R (2012) A review on medicinal plants with potential wound healing activity. International Journal of Pharma Sciences 2(4): 105-111.

2. Martin P (1991) Wound healing - aiming for perfect skin regeneration. Science 276(5309): 75-81.

3. Stuart E, David JL (2007) Basic science of wound healing. Surgery 26(2): 31-37.

4. Chitra P, Sajithalal GB, Chandrakasan G (1998) Influence of aloe vera on collagen turnover in healing of dermal wounds in rats. Indian Journal of Exp Biol 36(9): 896-901.

5. Nehete M, Nipanikar S, Kanjilal A, Kanjilal S, Tatke P (2015) Comparative efficacy of two polyherbal creams with Framycetin cream in treating fresh wounds. European Journal of Pharmaceutical And Medical Research 2(5): 1047-1057.

6. Raina R, Parwez S, Verma PK, Pankaj NK (2008) Medicinal plants and their role in wound healing. Vet Scan 3(1): 21-26.

7. Clark R (1991) Cutaneous Wound Repairs. In: Physiology, BioChemistry and Molecular Biology of Skin. Goldsmith La (Ed.). Oxford University Press, New York, USA, pp. 576.
8. Bhadoriya1 U, Suthar A, Dubey S, Aggarwal N (2010) Diuretic activity of methanolic extract of leaves of salvadora persica l. Rom J Biol. Plant Biol 55(1): 3-7.

9. Hassan S, Mohammed NAY, Leonard W (2011) Ethnobotanical and antibacterial potential of Salvadora persica l: a well- known medicinal plant in Arab and Unani system of medicine. Journal of Medicinal Plants Research 5(7): 1224-1229.

10. Emira N, Mejdi S, Najla T, Hafedh H, Riadh K, et al. (2011) Antibacterial, anticandidal and antioxidant activities of Salvadora persica and Juglans regia extracts. Journal of Medicinal Plants Research 5(17): 4138-4146.

11. Verma R, Purohit S, Bhandari A, Purohit P (2010) Analgesic and antiinflammatory activities of ethyl acetate extract of leaves of Salvadora persica L. International Journal of Pharmaceutical and Biological Archives 1(1): 51 -55.

12. Aberoumand A, Deokule SS (2008) Comparison of phenolic compounds of some edible plants of Iran and India. Pakisthan Journal of Nutrition $7(4): 582-585$.

13. Andrew L. (2002) Determination of total phenolics. Current Protocols in Food Analytical Chemistry I1: 1.1-I1.1.8.

14. Chen JC (2007) Phenolic content and DPPH radical scavenging activity of yam-containing surimi gels influenced by salt and heating. Asian Journal of Health and Information Sciences 2(1-4): 1-11.

15. Balavoine GA, Geletii V (1999) Peroxynitrite Scavenging by Different Antioxidants. Biology and Chemistry 3(1): 40-54.

16. Thaiponga K, Boonprakoba U, Crosby K (2006) Comparison of ABTS, DPPH, FRAP, and ORAC assays for estimating antioxidant activity from guava fruit extracts. Journal of Food Composition and Analysis 19(6-7): 669-675.

17. Heatley NG, Florey HW, Chain E, Jennings MA, Sander AG, et al. (1949) Antibiotics. Vol. I, Oxford University Press, New York, USA, pp. 130.

18. Organization of Economic Co-Operation and Development (OECD) (2002) Guidelines for Testing of Chemicals. No. 404. Acute Dermal Irritation /Corrosion, Paris, France.

19. Draize JH, Woodard G, Calvery HO (1944) Methods for the study of irritation and toxicity of substances applied topically to the skin and mucous membranes. Journal of Pharmacology and Experimental Therapeutics 82(3): 377-390.

20. Morton JP, Malone MH (1972) Evaluation of vulnerary activity by an open wound procedure in rats. Arch Int Pharmacodyn Ther 196(1):117-126.

21. Lee KH (1968) Studies on the mechanism of action of salicylate II; retardation of wound healing by aspirin. J Pharm Sci 57(6): 1042-1043.

This work is licensed under Creative

Commons Attribution 4.0 License

DOI: 10.19080/JCMAH.2018.07.555720

\section{Your next submission with Juniper Publishers will reach you the below assets}

- Quality Editorial service

- Swift Peer Review

- Reprints availability

- E-prints Service

- Manuscript Podcast for convenient understanding

- Global attainment for your research

- Manuscript accessibility in different formats

( Pdf, E-pub, Full Text, Audio)

- Unceasing customer service

Track the below URL for one-step submission

https://juniperpublishers.com/online-submission.php 